\title{
REGIONAL IDENTITY: A KEY TO OVERCOME STRUCTURAL WEAKNESSES IN PERIPHERAL RURAL REGIONS?
}

\author{
Sabine Sedlacek ${ }^{1}$, Bernhard Kurka ${ }^{2}$ and Gunther Maier ${ }^{3}$
}

Received 19 June 2008; Accepted 18 September 2009

\begin{abstract}
Depopulation is a well-known phenomenon in peripheral rural regions. The most identified problems are based on structural weaknesses in terms of decreasing business activities and a lack of public infrastructure. In such regions population is mainly older causing major changes in social infrastructure. For instance many schools and kindergartens close down for lack of demand, which hinders young families to migrate to such regions. The result is typically a negative cumulative process of loss of population, loss of jobs, loss of infrastructure, further outmigration. It is an enormous challenge for such regions to overcome this vicious circle. Regional identity can be seen as an important factor to overcome such structural weaknesses. The paper will discuss the concept of regional identity in order to define the term and how it is embedded in regional development theory. The empirical analysis is presenting results focusing on regional identity coming out of a qualitative data analysis and a postal survey. We designed a regional identity index, which measures the intensity of personal and social relationships of both inmigrants and out-migrants.
\end{abstract}

Keywords: regional identity, rural regions, in- and out-migration, endogenous regional development, governance

Zusammenfassung: Periphere ländliche Regionen sind vielfach durch eine stetige Abwanderung gekennzeichnet. Die häufigste Ursache wird in der wirtschaftlichen Strukturschwäche geortet, die vor allem die Funktion Arbeiten in erheblichem Ausmaß gefährdet. Die bedeutendsten Folgeprobleme der Abwanderung sind aus demographischer Sicht die Überalterung und aus versorgungstechnischer Sicht die Ausdünnung der Infrastruktur, insbesondere der sozialen Infrastruktur. Es entsteht ein negativer zirkulär-kumulativer Prozess, der zu weiteren Verlusten an Bevölkerung, Arbeitsplätzen, Versorgungseinrichtungen, Infrastruktur usw. führt und die Handlungsfähigkeit der Region maßgeblich einschränkt. Daher stellt das Durchbrechen dieses Teufelskreises eine der wichtigsten Herausforderungen für viele periphere ländliche Regionen dar. Die Rolle der regionale Identität zur Lösung derartiger struktureller Probleme ist noch zunehmend unterbelichtet. Der vorliegende

\footnotetext{
${ }^{1}$ Dr. Sabine Sedlacek, Assistant Professor, Department of Public Governance and Management, MODUL University Vienna, GmbH., Am Kahlenberg 1, 1190 Wien, Austria, e-mail: sabine.sedlacek@modul.ac.at

2 Mag. Bernhard Kurka, Researcher, Institute of Regional Development and Environment, Wirtschaftsuniversität Wien, Augasse 2-6, 1090 Wien, Austria

${ }^{3}$ Ao.Univ. Prof. Dr. Gunther Maier, Institute of Regional Development and Environment, Wirtschaftsuniversität Wien, Augasse 2-6, 1090 Wien, Austria; e-mail: gunther.maier@wu-wien.ac.at
} 
Beitrag fokussiert auf das Konzept der regionalen Identität, wobei die Frage der Definition des Begriffes und dessen Einbettung in die Regionalwissenschaften näher beleuchtet wird. Die empirische Analyse präsentiert identitätsbezogene Ergebnisse einer umfangreicheren Studie im Rahmen derer eine Fragebogenerhebung, Tiefeninterviews und eine Makrodatenanalyse durchgeführt wurden. Für diesen Artikel haben wir einen Index der regionalen Identität entwickelt, der die Intensität der persönlichen und sozialen Beziehungen von Zu- und Abwanderern misst.

Schlüsselwörter: Ältere Menschen / Demographischer Wandel / Lebensqualität / Ländlicher Raum / Ländliche Entwicklung

\section{Introduction}

Regional development theory as well as regional development policy provides arguments that regional identity in a population is favourable for regional development. As argued by Roca and Oliveira-Roca (2002), the "strengthening of the identity of the peripheral and lagging rural regions" is a major aim in the European Union and is seen as "the key to their competitiveness on the global market of goods, services and ideas" (p. 434). In the EU's Regional Programmes for Innovative Actions 2000-2006, "regional identity and sustainable development" was one of the three broad themes. In the theoretical discussion, identity is embedded in various regional economic and economic geography concepts of development (see Tab 1) such as milieu (Aydalot and Keeble 1988, Camagni 1991, Crevoisier 1993, Maillat 1991, Ratti et al. 1997), endogenous development (Andersson 1985, Goldstein 1991, Stöhr 1987, Tödtling 1990), social capital (Putnam 1993 and 2001, Schuller 2007, van Staveren and Knorringa 2007) and new regionalism (Amin 1999 and 2002, Deas and Lord 2006, Lovering 1999, Storper 1997). These concepts have widespread foci and are in a certain manner not well defined. For instance, Ann Markusen (1999) criticised some of them as 'fuzzy conceptualization'. What they have in common is a qualitative approach focussing on soft factors of regional development. Additionally all these concepts state a high importance of regional stakeholders and their ability to cope with specific regional circumstances. Tab 1 summarises for each concept the general characteristics and arguments that underline the importance of regional identity. In terms of their main focus, the concepts are quite similar and refer to each other. The concepts of milieu and endogenous development focus mainly on specific institutional prerequisites which support the regional development process. The social capital concept underlines the importance of social relations between actors and their skills and competences. In contrast to these economic and individual based views, new regionalism stresses the question of governance and empowerment which puts emphasis on the decision making process. Their main argument is territorial re-organisation and rescaling of governance (Deas and Lord 2006).

Regional stakeholders are an important factor in all these concepts. There is a broad correspondence between the importance of networks and collective actions. Personal relationship between the regional stakeholders is argued to be an important success factor underpinned in the four approaches. As Schuller (2007) pointed out "social capital is sometimes treated as an individual asset...... but is most powerfully applied to the relationships that exist within and between social networks". At the regional level a comprehensive analysis of social capital is the most effective way to value particular skills and competences (Schuller 2007). This broader view on relationships between social networks is unique in the social capital approach. The other concepts concentrate on the relationships within each network.

The approaches agree in considering region specific knowledge as a key-factor for innovationbased regional development. That a specific regional consciousness or identity could support the regional development process is implicit in each of the four concepts. The milieu approach refers to weaknesses in problem regions. Aydalot (1986) argued that specific regional social links are preventing migration, an argument that stresses the actor's solidarity with the region. Solidarity is one elementary aspect of regional identity. Tödtling (1990) pointed out that a specific cultural, psychological and political background supports innovation, an argument of endogenous development that perfectly fits the regional identity approach. Edwards and Foley (1997) are stating an embeddedness of cultural factors, such as identities and aspirations, within the social capital discussion. Finally, there are strong arguments coming from the new 
regionalism debate, where social structures and cultural factors form a specific "regional culture" (Amin and Thrift 1992).

The regional planning and human geography literature provides different interpretations of regional identity (for an overview see ARL 2005) which will be further discussed in the following section. One is regional consciousness which covers the arguments collected above.

This paper is based on the assumption that regional identity is an important factor to overcome regional crises in problem areas such as peripheral regions. A more detailed look often shows a more differentiated picture and offers opportunities for policy action. First, although people are moving out of these locations new in-migrants are interested in such peripheral regions and their strengths, such as silence, a beautiful natural landscape. Second, new technologies enable skilled personnel to work without urban infrastructure and face-to-face networks. Third, there is an enormous potential in people who moved but do maintain permanent contact with their home region in terms of regaining them after retiring. Consequently, the main goal of this paper is to identify whether and to what extent regional identity exists among in- and outmigrants of our study region, a peripheral rural area in Austria. Moreover, we want to find out whether there are particular groups in the population who show a higher level of regional identity than others.

The paper is organised along four sections. Section 2 provides the theoretical background of regional identity. It clarifies the term "identity" and its regional implications. In section 3 we present and discuss empirical evidence coming from a survey based research in a peripheral rural region in Austria that suffers from depopulation and is caught in a negative cumulative process. The final section summarises the main findings and draws some conclusions.

\section{Regional identity}

The roots of the concept of regional identity are in human geography and were further developed in regional planning. Particularly German speaking geographers of the 1980s dealt with regional identity in a broader context and developed a conceptual framework (see Blotevogel et al. 1989, Derenbach 1988, Ipsen 1993, Weichart 1990). In this literature regional identity is discussed in close connection with "regional consciousness" ("Regionalbewußtsein"). Outside the German speaking community a major contribution came from Paasi $(1991,2002 a)$. He linked the institutionalisation process of a region with its regional identity.

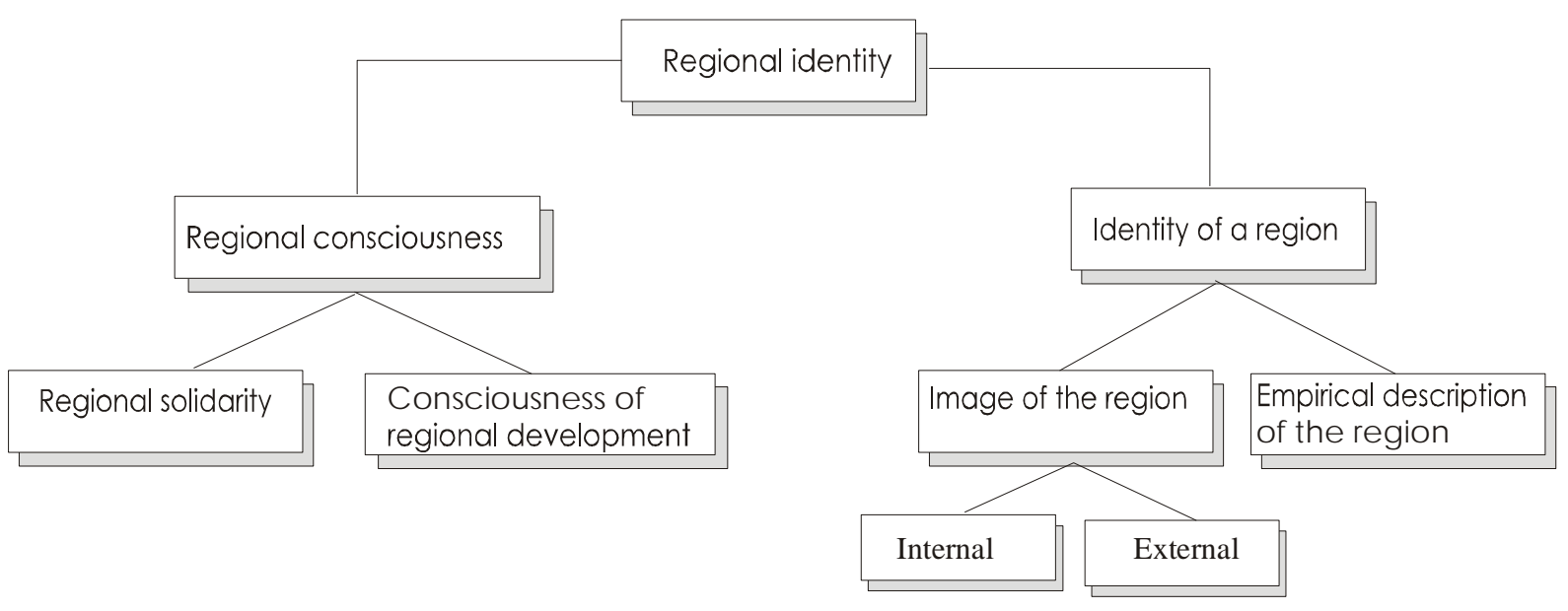

Fig 1. Regional identity. Source: ARL (2005). 


\begin{tabular}{|c|c|c|c|}
\hline & 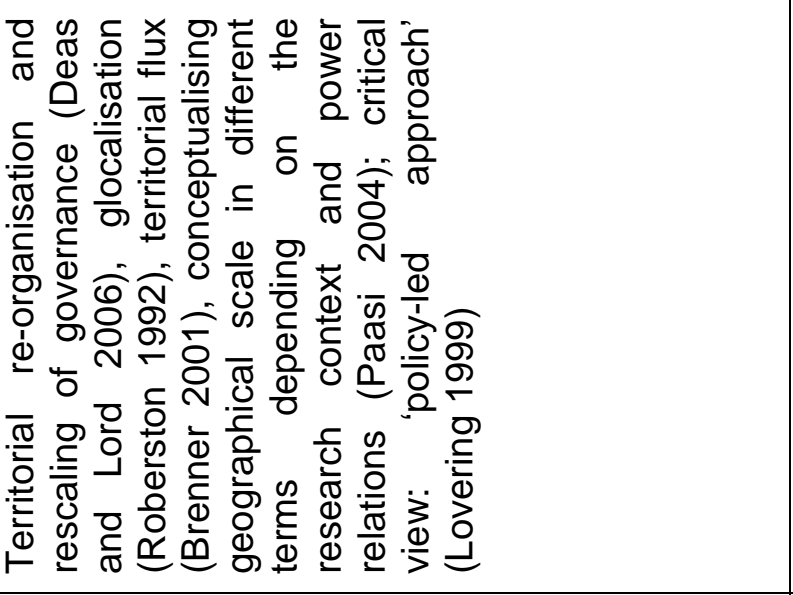 & 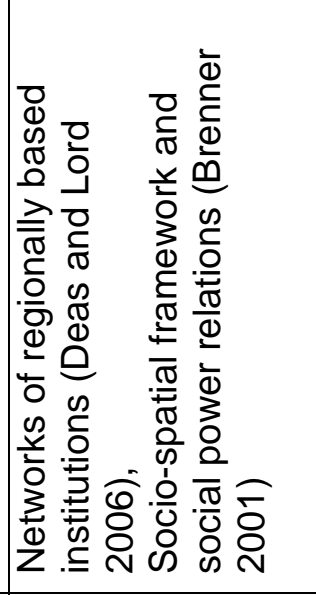 & 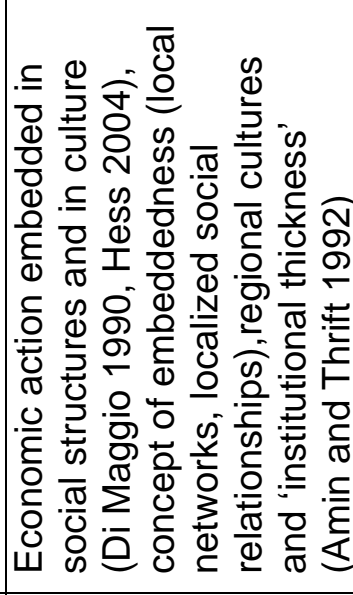 \\
\hline & 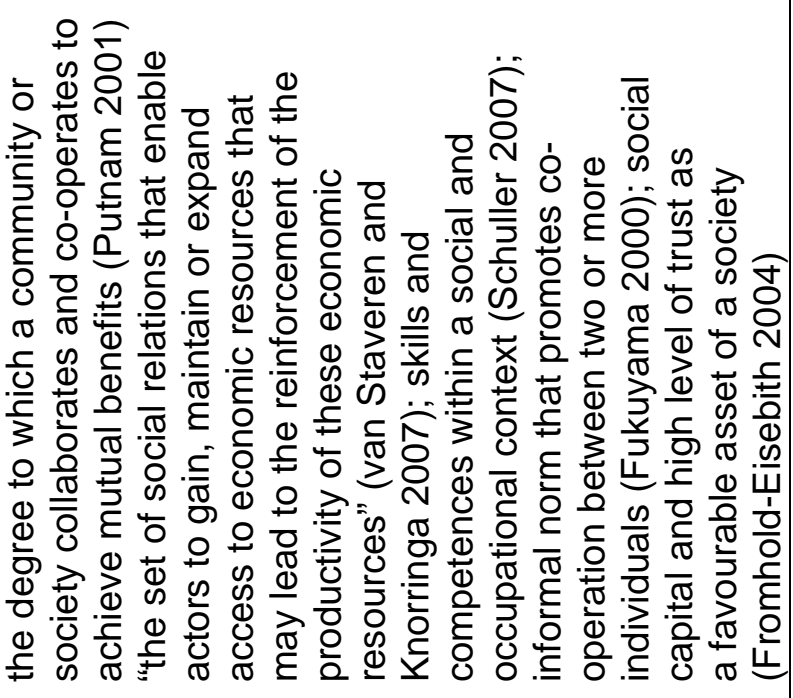 & 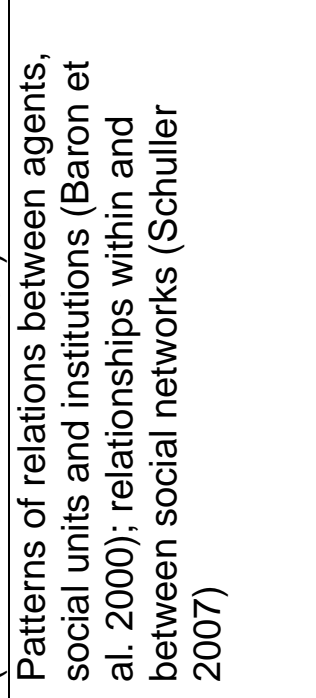 & 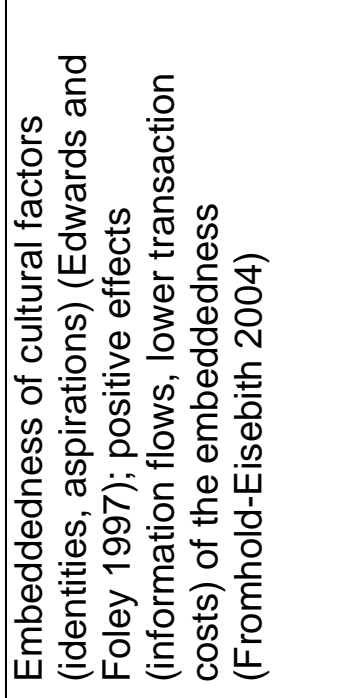 \\
\hline & 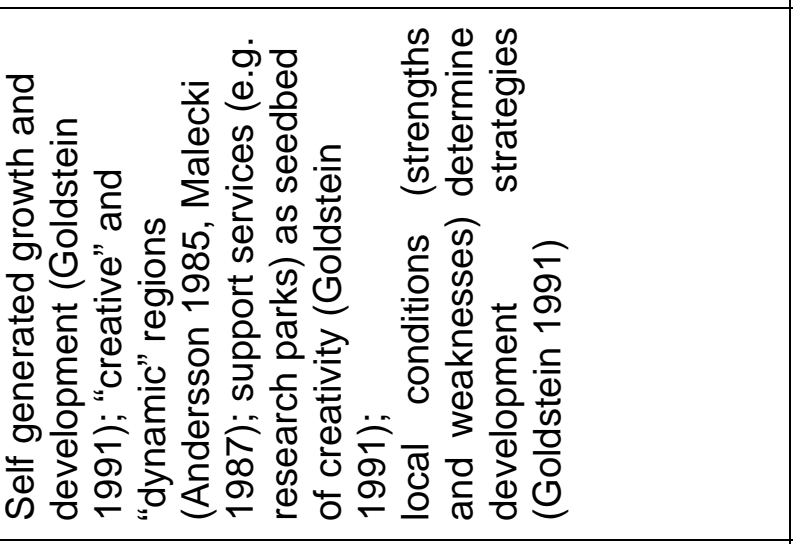 & 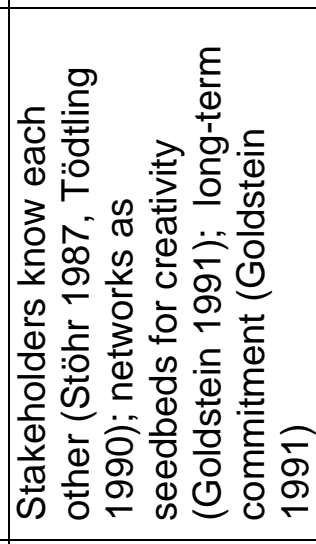 & 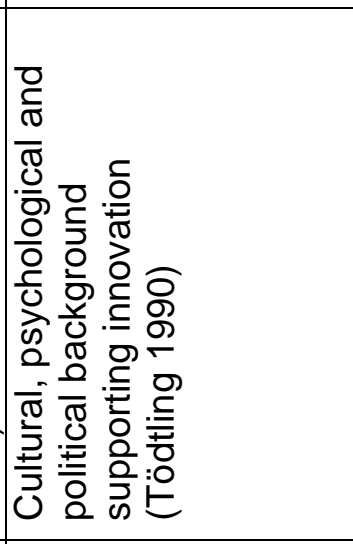 \\
\hline & 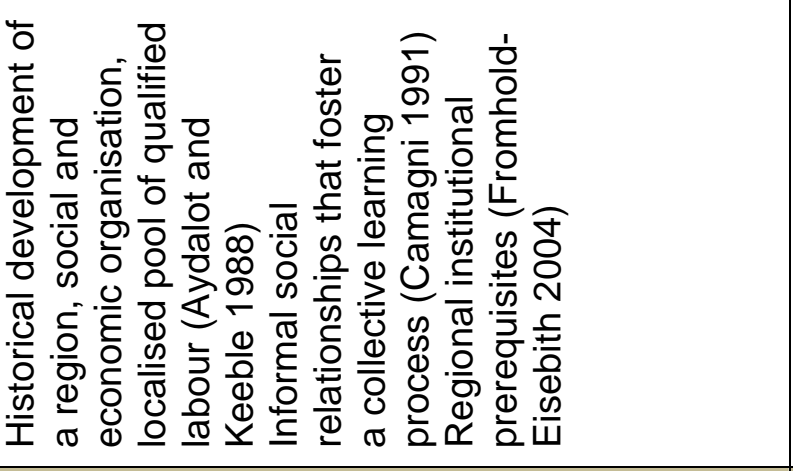 & 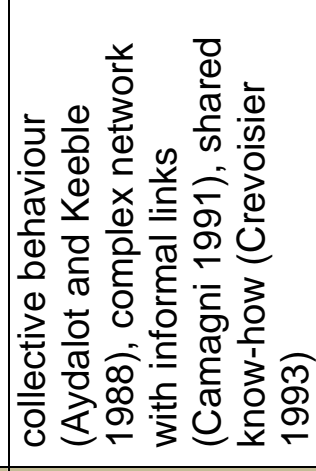 & 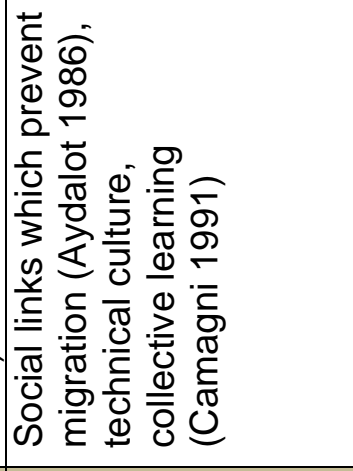 \\
\hline & 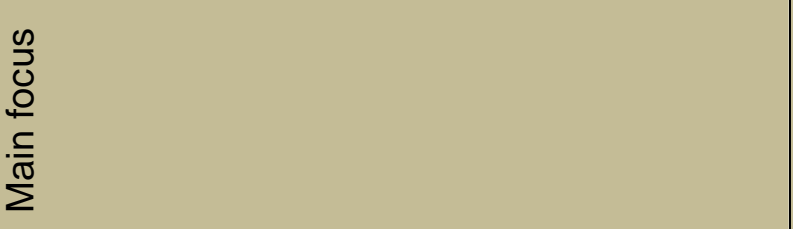 & 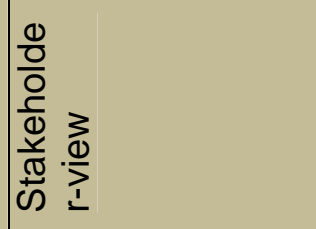 & 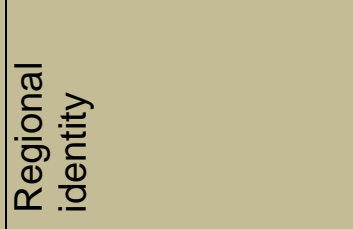 \\
\hline
\end{tabular}


In general the concept of regional identity is not well defined. Paasi (1991), for example refers to regional identity as "the collective work of individuals for the region". One problematic element is that of the region which can be of very different size and structure. On the other hand the sociological concept of identity is fuzzy as well.

The German handbook of spatial planning (ARL 2005) provides an overview of the holistic concept of regional identity that relates regional consciousness and identity of a region (see Fig 1).

The term identity of a region (see Fig 1 ) covers two implicit aspects. On the one side it relates to the image of a region which is subdivided in internal and external image. Internal image depends upon people's identification with the region although the image component covers mainly descriptive elements and can be defined as the internal perception of the region. On the other side the empirical description of a region characterises the region's economy, society and the environment. According to this classification a region is the sum of functional relations and social interactions without strict borders.

Regional consciousness (see Fig 1) covers two important aspects. Regional solidarity is one aspect functioning as a landmark of a particular region which implies a specific relationship with the region. Inhabitants are proud to be part of the region and have a strong territorial connection. In a certain way it is synonymous with native land and was intensively analysed in the German human geography community of the nineteen eighties (Bausinger 1980, Derenbach 1988, Blotevogel et al. 1989). The more development oriented aspect is subsumed under consciousness of regional development ("regionales Entwicklungsbewußtsein", see Fig 1).

Blotevogel et al. (1989) argue that regional consciousness is the amount of spatial attitudes and identifications. Concerning space and/or region and attitudes three different dimensions are evident (Blotevogel et al. 1989, p. 71f.):

The cognitive dimension is defined as the attitude towards the region (physical and spatial elements, borders, culture, organisations, etc.). People have to be aware of the region and its geographical limits. Keating (1998a, p. 86) argues that "this requires knowledge of other regions, with which the home region can be compared and from which it can be differentiated".

The affective dimension refers to a common regional solidarity or identity and native land, what in German language is referred to as "Heimat". This dimension covers personal and emotional needs and satisfaction and provides information about how people feel about the region.

The conative or instrumental (see Keating 1998a) dimension focuses on specific stakeholder actions. In this context social integration such as collective active participation in regional institutions or organisations (church, political parties, associations, etc.) and active commitment and engagement provide arguments for regional consciousness. The main argument is that an intensive participation reduces the probability of out-migration. As Keating (1998a, p. 86) pointed out "these goals may include the attainment of regional autonomy, or they may be focused on more immediate social and economic policies, to be achieved through the existing structures".

Weichart (1989) amplified these dimensions and developed three basic dimensions of territorial identity:

Identity of a place: can be summarised as individual identity focussing on the cognitiveemotional knowledge. Sociology defines it as the specific stock of knowledge.

Identification with a place: is the result of a self-reflective process of an individual and is manifested in specific roles and the relationship with a particular region.

Social spatial identification: covers social systems such as groups, organisations and classes with a joint consciousness. The spectrum ranges from diffuse connections to active commitment. The spatial relations within such social systems are manifold. Firstly, it is relevant for the territorial delimitation, for instance neighbourhood, municipality, and nation. Secondly, it refers to the physical elements of landscape, for instance mountains, rivers, monuments. Thirdly, it is relevant via organisations with a concrete spatial connection, for instance regional planning organisations or natural protection organisations. 
The more recent work in the field of territorial identity brings into the discussion new forms of governance in the region. Donaldson (2006) links European regional policy with the discussion of language and identity. He identified a focused discussion among social scientists concerning "new modes of development and governance in the region" (e.g. Keating 1998a; 1998b, MacLeod 2001, MacLeod and Jones 2001, Paasi 2002b, Keating 2004). Ray (1999) maintains that territorial identity represents an emerging form of local governance especially in the field of rural development. He links territorial identity with endogenous development (Stöhr 1987, Tödtling 1990) and identifies cultural, historical and physical sources of an identity of the territory (Ray 1999, p. 259). He maintains that "the endogenous approach is used particularly for areas which have relative socio-economic problems" (Ray 1999, p. 259). For this so-called endogenous territorial approach to socioeconomic development (Donaldson 2006, p. 2076), local culture and political participation are central. Both are elementary factors in the sustainable development process. The recent debate about institutionalizing sustainable development (OECD 2007) includes the implementation of governance structures for sustainable development strategies. Additionally a growing body of literature deals with governance for sustainable development (see Lafferty 2004, Voß et al. 2006, van Huijstee et al. 2007, Dobson 2007) which is strongly linked to participative approaches. Participation or effective stakeholder involvement is one of the core indicators in the OECD checklist on improving policy coherence and integration for sustainable development (OECD 2002).

Roca and Oliveira-Roca (2007, p. 436) define territorial identity as "a set of spatial fixes and flows that mark a geographical unit such as a place, or a region". In their diction spatial fixes are the "sum of permanently or temporarily rooted and/or anchored elements of the natural heritage, population and human made economic and cultural heritage in a geographical area" (Roca and Oliveira-Roca 2007, p. 436).

In linking identity and space it seems important to differentiate between individual and collective consciousness (Paasi 1991) which means that the "sense of place is more than just one person's feelings about a particular place" (Rose 1995, p. 89). In this context Paasi (1991) referred to different spheres of social action and consciousness. He concluded that regional identity may be "an important component of territoriality in various contexts and a significant element in the construction of regions as meaningful socio-political spaces" (Paasi 2002a, p. 138). According to this, regional identity is an important factor for regional development strategies and can be used as an "approach to attach people and to raise consciousness of locality as the unit of development policy and action" (Ray 1999, p. 259). There are several examples of LEADER+ regions $^{4}$ across Europe (European Commission 2006) stressing territorial cohesion by following the modes of governance (including survival, identity, power, legitimacy, achievement, equality, uniqueness, sustainability - see Lukesch 2007, p. 14).

Besides the distinction of individual and collective identity Keating (1998a, p. 87) refers to the importance of a differentiation of local and regional identity, which is linked to the question of scale and the definition of regions (see Keating 2003, p. 256f.). According to Keating (1998a, p. 87) "local identity is predominantly based on a personal experience, individual contact and events of everyday life, whereas regional identity is a social construction forged in a specific context under the influence of social, economic and political pressures". But the distinction between local and regional identity is malleable in terms of the different scales of regions that we find especially if we compare for instance NUTS 3 regions across Europe.

\footnotetext{
${ }^{4}$ http://leaderplus.ec.europa.eu/cpdb/public/gpdb/GpdbSearchFS.aspx?language=en
} 


\section{Regional Identity - an empirical analysis}

The empirical analysis of regional identity is based on the research project "Menschen+", which aimed at developing regional policy strategies for the shrinking region ${ }^{5}$ "Waldviertler Wohlviertel Thaya-Taffa-Wild". We followed a step-by-step research design covering a quantitative data analysis, a postal survey and face-to-face in depth interviews. The empirical basis for the paper at hand originates from the survey.

\subsection{The case study region}

The LEADER $+{ }^{6}$ region under study "Waldviertler Wohlviertel Thaya-Taffa-Wild" or "Waldviertler Wohlviertel" for short is located in the north eastern part of Austria and belongs to the NUTS3 region "Waldviertel" in the province of Lower Austria. The region as it was defined in the LEADER+ period 1999-2006 consists of nine municipalities (Brunn/Wild, DrosendorfZissersdorf, Geras, Irnfritz-Messern, Japons, Langau, Pernegg, St. Bernhard-Frauenhofen, Weitersfeld) in the district Horn (see

Fig 2). With a surface area of $414 \mathrm{~km}^{2}$ the region had 10,367 inhabitants in 2001. "Waldviertler Wohlviertel" is a typical rural peripheral border region (Drosendorf-Zissersdorf and Langau border the Czech Republic). About $64 \%$ of the surface area is agricultural land. Population density is extremely low (between 20 and 45). In terms of infrastructure and the supply of goods and services the region shows major weaknesses. This is mainly caused by a lack of centres within the region. The nearest regional centre in the political district is Horn (6,300 inhabitants) located next to the case study region (St. Bernhard-Frauenhofen borders Horn). The regional centre Horn shows growth of population (+2.3\% 1991 - 2001) and economic activities (+22\% jobs and $+33 \%$ employment 1991 - 2001) caused by a positive migration balance $(+4.5 \%$ between 1991 and 2001). Due to a lack of jobs and infrastructure out-migrants of "Waldviertler Wohlviertel" often migrate to Horn. The study area suffers from rural depopulation which is a widespread phenomenon in many parts of Europe (Stockdale 2006). Stockdale (2002) maintains that "rural out-migration continues, and that depopulation remains the most pervasive demographic feature of many remote or peripheral areas" (p. 345).

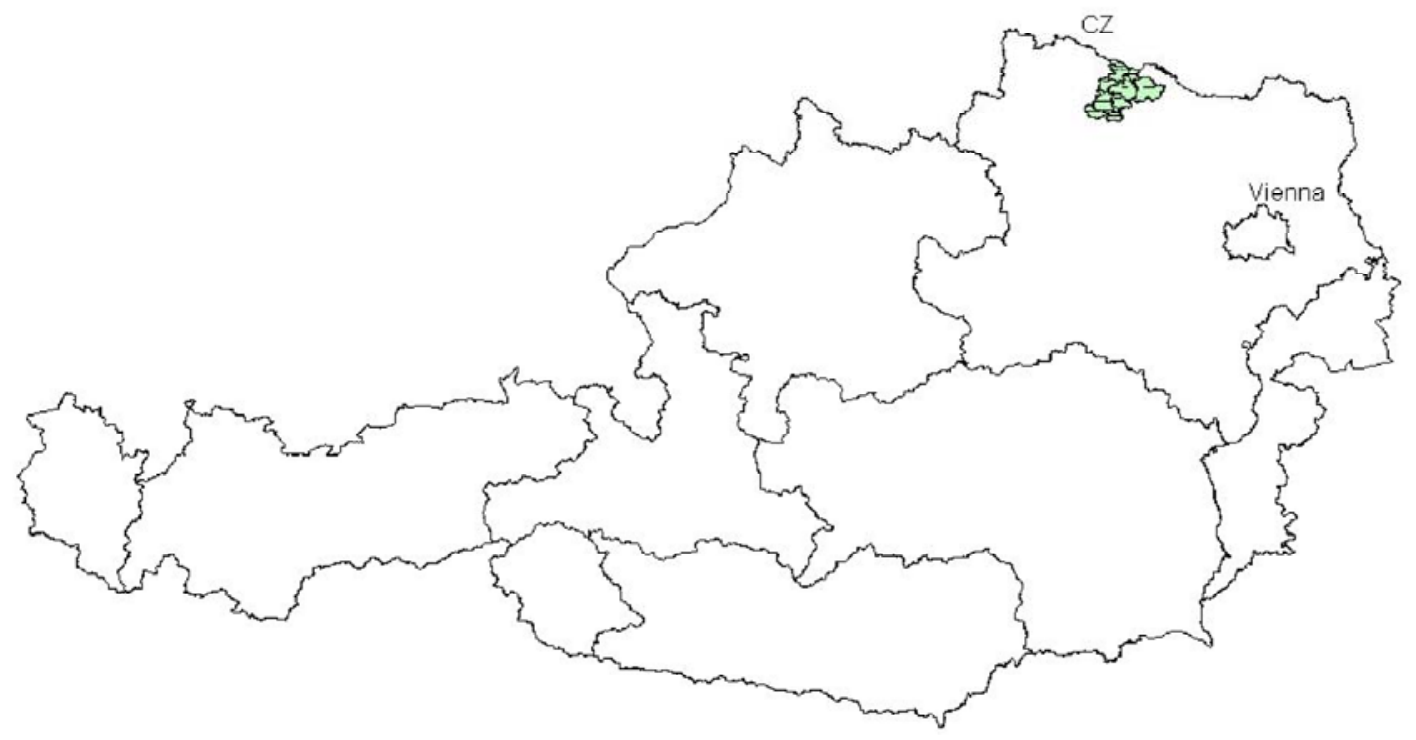

Fig 2. The case study region "Waldviertler Wohlviertel". Source: own design.

The case study region can be classified as a shrinking region due to a major loss of population, employment, and infrastructure. Out-migration (migration balance: -1.5\% 1991-2001) and a negative natural population change $(-2.9 \%$ 1991-2001) are the most pressing problems in "Waldviertler Wohlviertel". The dynamic development of Horn (pull factors) and the permanent

\footnotetext{
${ }^{5}$ Shrinking regions are defined as regions with a major loss of population, jobs and infrastructure.

${ }^{6}$ LEADER+ period 1999-2006
} 
negative trend in the case study region cause a negative cumulative process driven by a loss of population, loss of jobs, loss of infrastructure and further out migration (push factors) in the Waldviertler Wohlviertel. Despite this negative cumulative process the region attracts inmigrants, people who are in search of silence, an intact natural landscape and a kind of slowness and relaxation. The case study analysis aims at identifying opportunities and strategies for counter action.

\subsection{Sample and sample characteristics}

In order to find out and analyse motives for in- and out-migration we conducted a questionnaire based survey. We focused on in-migrants and out-migrants during the period 1995 and 2005 (full survey). Tab 2 shows the details of the survey. The addresses were provided by the municipalities and the quality of this data varied strong. Especially the address data for outmigrants were partly incorrect which is expressed in a relatively high share of undeliverable questionnaires. With $19 \%$ the response rate of in-migrants seems relatively low at first sight, but it is in the range of other citizens' surveys in Austria. The reason for such low respond rates is based on the fact that every member of a household received the same questionnaire which may lead to a reduced willingness to fill it in. The respond rate of the out-migrants lies with $16 \%$ above our expectations because of the long time period back to 1995. Many of the out-migrants did identify with their former residential region. Nevertheless, the low respond rates have to be taken into account when interpreting the results. This is the reason why we utilize in the interpretation the other empirical components of the step-by-step research (see above) covering a quantitative data analysis and in depth interviews besides the survey.

In order to gather a balanced picture about the strengths and weaknesses of the study region we interviewed both in-migrants and out-migrants ${ }^{7}$. The hypothesis is that people belonging to these two groups differ in their opinions and attitudes. The fact that in-migrants and outmigrants have knowledge about other regions permits a direct comparison which is essential for any assessment. On the one hand people who move out often stay in close contacts with their former home regions. They have family and/or friends there. These social contacts build up a special kind of regional identity which can be strengthened by criteria like natural landscape and silence. On the other hand people who moved in provide an insight of the specific attractiveness and/or other specific reasons which have influenced their decision to choose this particular region. People who did not move in or out during the period 1995 - 2005 were not included in this sample.

\begin{tabular}{lll}
\hline Questionnaire & In-migration & Out-migration \\
\hline sent & 1,369 & 1,345 \\
undeliverable & 18 & 409 \\
returned (filled in) & 261 & 152 \\
response rate & $19.32 \%$ & $16.24 \%$ \\
\hline
\end{tabular}

Tab 2. The questionnaire based survey. Source: survey.

We developed target group specific questionnaires (for in-migrants and out-migrants) with a common base line especially for regional identity aspects. The following tables (Tab 3, Tab 4, Tab 5) provide an overview of the general results for both in-migration and out-migration.

Concerning the age groups (see Tab 3 ) the sample covers a clear majority of female respondents in the largest age group $30-54$ years in both migrant groups. In total almost $40 \%$ of the in- and out-migrants belong to this age group. The other two age groups are relatively homogenous in terms of the gender distribution. In order to identify particular differences between female and male respondents the following analyses distinguish by both gender and migrant type.

\footnotetext{
${ }^{7}$ We included only those in- and out-migrants who were at least 18 years old in 1995.
} 


\begin{tabular}{l|llll}
\hline Age group & \multicolumn{2}{|l}{$\begin{array}{l}\text { In-migration }(\%) \\
\text { female }\end{array}$} & male $(n=103)$ & \multicolumn{2}{l}{ Out-migration $(\%)$} \\
& female $(n=91)$ & male $(n=62)$ \\
\hline $20-29$ & 50 & 50 & 50 & 50 \\
$30-54$ & 79 & 21 & 74 & 26 \\
$55+$ & 58 & 41 & 56 & 44 \\
\hline
\end{tabular}

Tab 3. Number of respondents by age and migrant type. Source: survey.

Tab 4 reveals that mainly employed and retired people responded. The female sample shows two different characteristics compared to the male respondents. Besides being employed and retired women are often housewives (in-migrants: $\sim 21 \%$; out-migrants: $\sim 15 \%$ ). In the inmigrants' sample only female respondents are in education. As in many other studies (e.g. Stockdale et al. 2000, Stockdale 2006) unemployed people are hardly present in this survey.

\begin{tabular}{|c|c|c|c|c|}
\hline & \multicolumn{2}{|c|}{ In-migration (\%) } & \multicolumn{2}{|c|}{ Out-migration (\%) } \\
\hline & $\begin{array}{l}\text { female } \\
(n=152)\end{array}$ & male $(n=103)$ & female $(n=91)$ & male $(n=62)$ \\
\hline Employed & 51.0 & 64.1 & 64.8 & 72.6 \\
\hline Unemployed & 2.0 & 0.0 & 2.3 & 3.2 \\
\hline Military or civilian service ${ }^{8}$ & 0.0 & 0.0 & 0.0 & 1.6 \\
\hline Retired & 21.2 & 35.9 & 13.6 & 19.4 \\
\hline Housewife & 21.2 & 0.0 & 14.8 & 0.0 \\
\hline Training & 4.6 & 0.0 & 4.5 & 3.2 \\
\hline
\end{tabular}

Tab 4. Employment status by migrant type. Source: survey.

At first sight, the hypothesis that highly skilled people more often belong to the out-migrants does not seem to be supported by the data. The sample includes relatively few respondents with a University degree and there are slightly more female in-migrants (22 women) with a University degree included in the sample (see Tab 5). Aggregating the education levels to three groups, "primary", "secondary" and "tertiary education", the shares indicate a converse picture. Out-migrants (21\% of males and $19 \%$ of females belong to the group "tertiary education", $44 \%$ of males and $41 \%$ of females belong to the group "secondary education") are definitely better educated than in-migrants (16\% of males and $18 \%$ of females belong to the group "tertiary education", $27 \%$ of males and $30 \%$ of females belong to the group "secondary education").

\begin{tabular}{|c|c|c|c|c|c|}
\hline \multirow{2}{*}{\multicolumn{2}{|c|}{ Education level }} & \multicolumn{2}{|c|}{ In-migration (\%) } & \multicolumn{2}{|c|}{ Out-migration (\%) } \\
\hline & & $\begin{array}{l}\text { female } \\
(n=152)\end{array}$ & $\begin{array}{l}\text { male } \\
(n=103)\end{array}$ & $\begin{array}{l}\text { female } \\
(n=91)\end{array}$ & $\begin{array}{l}\text { male } \\
(\mathrm{n}=62)\end{array}$ \\
\hline \multirow[t]{2}{*}{$\begin{array}{l}\text { Tertiary } \\
\text { education }\end{array}$} & $\begin{array}{l}\text { University, institution of } \\
\text { higher education } \\
\text { Vocational college, teacher }\end{array}$ & 14.7 & 13.7 & 11.2 & 17.7 \\
\hline & training college & 3.3 & 2.0 & 7.9 & 3.2 \\
\hline \multicolumn{2}{|c|}{ Total tertiary education } & 18.0 & 15.7 & 19.1 & 20.9 \\
\hline \multirow{3}{*}{$\begin{array}{l}\text { Secondary } \\
\text { education }\end{array}$} & Further education college & 2.7 & 2.0 & 0.0 & 3.2 \\
\hline & Vocational high school & 16.0 & 17.6 & 27.0 & 33.9 \\
\hline & High school & 11.3 & 6.9 & 13.5 & 6.5 \\
\hline \multicolumn{2}{|c|}{ Total secondary education } & 30.0 & 26.5 & 40.5 & 43.6 \\
\hline \multirow{3}{*}{$\begin{array}{l}\text { Primary } \\
\text { education }\end{array}$} & Vocational middle school & 14.7 & 15.7 & 14.6 & 6.5 \\
\hline & Apprentice training scheme & 21.3 & 37.3 & 15.7 & 22.5 \\
\hline & Compulsory education & 16.0 & 4.8 & 10.1 & 6.5 \\
\hline \multicolumn{2}{|c|}{ Total primary education } & 52.0 & 57.8 & 40.4 & 35.5 \\
\hline
\end{tabular}

Tab 5. Education level by migrant type. Source: survey.

\footnotetext{
${ }^{8}$ In Austria military and civil service is mandatory.
} 


\subsection{Major aspects of regional identity}

In order to identify in-migrants' and out-migrants' attitudes towards the case study region, we designed positive and negative statements and asked for the target groups' individual assessment (see Tab 6). The respondents had to assess each statement within a range of one ("fully agree") and six ("fully disagree"). Tab 6 shows a fairly similar distribution with an outstanding positive overall attitude for both in- and out-migrants. The region has a positive image and it seems that in-migrants rapidly develop a regional identity based on several characteristics. First of all the physical landscape and soft factors defining quality of life like recreation and silence (1.8) are estimated as clear strengths of the region. Secondly, the atmosphere for specific demographic groups (elderly people 2.8 and families with children 2.6) is estimated rather positively. Our provocative statements defining "Waldviertler Wohlviertel" as a "looser" region (S4: 5.0 and S5: 4.1) met no approval.

The results of the out-migrants' attitudes show a similar picture. People who left the region emphasise its relaxing potential more than in-migrants (out-migrants: 1.7 and in-migrants: 1.8, see table 4). The majority (54\%) of the respondents answered this question with 1 , which represents full agreement. The second aspect of a slightly more optimistic estimation is the atmosphere for families with children (out-migrants: 2.5 and in-migrants: 2.6 , see table 4), which can be interpreted as the regions' intact social and natural landscape. Many out-migrants are currently living in agglomeration areas with a comparatively anonymous image.

\begin{tabular}{|c|c|c|}
\hline Statements $^{9}$ & $\begin{array}{l}\text { Means in- } \\
\text { migrants }\end{array}$ & $\begin{array}{c}\text { Means out- } \\
\text { migrants }\end{array}$ \\
\hline $\mathrm{S} 1$ : The region is perfect for relaxation. & 1.8 & 1.7 \\
\hline S2: The region has cultural opportunities. & 2.6 & 2.9 \\
\hline $\begin{array}{l}\text { S3: During the past few years one has noticed a } \\
\text { growing climate of migration in the region. }\end{array}$ & 3.1 & 3.0 \\
\hline $\begin{array}{l}\text { S4: People can but only feel happy when they are } \\
\text { able to leave the region. }\end{array}$ & 5.0 & 4.8 \\
\hline $\begin{array}{l}\text { S5: The region has more of a climate of prevention } \\
\text { than progression. }\end{array}$ & 4.1 & 4.2 \\
\hline $\begin{array}{l}\text { S6: People do have good opportunities to establish } \\
\text { themselves in the region. }\end{array}$ & 3.9 & 4.2 \\
\hline $\begin{array}{l}\text { S7: The region provides a perfect atmosphere for } \\
\text { families with children. }\end{array}$ & 2.6 & 2.5 \\
\hline $\begin{array}{l}\text { S8: The region provides a perfect atmosphere for } \\
\text { elderly people. }\end{array}$ & 2.8 & 3.0 \\
\hline $\begin{array}{l}\text { S9: Spatial proximity to the border is an advantage } \\
\text { for the region. }\end{array}$ & 3.6 & 3.6 \\
\hline
\end{tabular}

Tab 6. Comparison of in-migrants' and out-migrants' means. Source: survey.

A rather surprising result is the absolute negative position of out-migrants via the provocative statements (S4: 4.8 and S5: 4.2). There is strong evidence that people who left the region had not accumulated negative feelings towards the region which was also approved by our in-depth

\footnotetext{
${ }^{9}$ As pointed out by an anonymous referee, the majority of the evaluation statements express a positive attitude, which may have tilted the answers toward the positive side. Based on the fact that some of the positively formulated statements are rejected by the majority of the respondents and the responses from the qualitative interviews, which are in line with these quantitative results, we are confident that such a bias if it exists is minimal.
} 
interviews. $41 \%$ of the respondents (out-migrants) answered statement 4 ("people feel happy when they are able to leave the region") with 6 , which represents full disagreement. We checked the personal ties to another section of the questionnaire and the results confirm the out-migrants positive attitude. Many of the out-migrants do have rather strong personal ties to their former home region, families and friends are still living there and they have intensive contacts to the region ( $\sim 40 \%$ visit the region more than once per month). More than $90 \%$ of the respondents do have a strong solidarity sense. The concrete question of intentions to return to their former home region shows a potential of about $40 \%$ of the respondents but only $26 \%$ are concretely planning such a return. A detailed analysis of age groups shows an interesting aspect. The group of the 30-54 years old out-migrants can be seen as the potential returnees (30.8\% of this age group are planning to return).

In comparison the elderly people (age group 55+) are more sceptical concerning a potential return (only $20 \%$ are planning to return). These results strengthen the picture of a calm atmosphere for families with children estimated positive by both in-migrants and out-migrants.

In order to receive a clear picture of the strengths and weaknesses we designed a list of basic demands and needs and asked the respondents to define them as strength or weakness. Additionally we conducted open questions to complete and clarify these aspects. The region shows one major weakness - lack of jobs. $80.6 \%$ of the in-migrants and $90 \%$ of the outmigrants defined the shortage lack of jobs as the major weakness. Out-migrants identified pupils' after school care (>50\%) and local retailing (>40\%) as existing weaknesses. The open questions delivered additional problems like public transport. Asking for the strengths of the region shows a broad range of positive aspects - housing ( $70 \%)$, kindergartens (in-migrants: $>67 \%$, out-migrants: $>50 \%$ ), schools (in-migrants: $\sim 60 \%$, out-migrants: $\sim 50 \%)$, leisure $(\sim 50 \%)$, recreation ( $-90 \%)$ and cohesion ( $60 \%)$. Housing was indicated as one of the major strengths in the region which has several reasons. Real estate prizes are relatively low compared to urban areas and the region seems to provide a rather intact environment. Landscape was identified as one of the positive key factors in the study region. The out-migrants' sample shows one age group (+55 years) which improved its housing situation after migrating. More than $60 \%$ of elderly out-migrants are older than 65 years which suggests that these people have been mainly looking for specific housing opportunities for their retirement. The open questions completed this positive picture, mainly including a wide range of identity based factors, like for instance intact nature, silence, organic farming combined with tourism and recreation (sustainable tourism).

\subsection{A regional identity index}

The assessment statements (see Tab 6) that we have discussed in the previous section characterize various aspects of regional identity. In this section we use them to generate an index of regional identity and a score of this index for every respondent. In the following section we will compare the average index scores - the "regional identity" - of various groups in the population.

We use principal component factor analysis to derive the index. Since one of the aims of this step is to be able to compare the regional identity levels of in- and out-migrants, we merge the two subgroups for this step of the analysis. As a consequence, the factor loadings and factor scores reflect the assessment of both, in- and out-migrants.

When we apply a principal component factor analysis to the nine assessment statements and use the standard cut-off criterion (eigenvalue $>1$ ), we get two components. The respective factor loadings are shown in Tab 7.

The analysis raises the usual problem of how to interpret the resulting components. More specifically, in our context we need to find out which of the two components comes closest to measuring "regional identity". When we look at the assessment questions we find that statements 1-3 and 6-9 are stated positively, whereas statements 4 and 5 are negatively formulated. In all cases lower values represent higher agreement. So, for individuals with high levels of regional identity we would expect high agreement (low values) for the first group of statements, but low agreement (high values) for the second group of statements. Consequently, a component measuring regional identity would need to have factor loadings with reverse signs 
for the two groups of questions. This is exactly the sign pattern that we find for the first component. Therefore, we interpret this component as "regional identity" and use the factor scores of the respondents as their measure of regional identity. The first component captures approximately one third of the variance in the dataset. We do not interpret or use the second component. We only note that its factor loadings seem unrelated to any type of regional identity.

Factor scores resulting from principal components factor analysis are always standardized to mean zero and variance one. Therefore, the regional identity index cannot be used to measure the level of regional identity of the overall sample. It can only be used to compare the regional identity of various groups of respondents. For the most important socio-economic groups this will be done in the following section of the paper.

\begin{tabular}{|l|r|r|}
\hline & component 1 & component 2 \\
\hline variance explained & $33.25 \%$ & $13.16 \%$ \\
\hline S1 & 0.550 & 0.523 \\
\hline S2 & 0.541 & 0.632 \\
\hline S3 & 0.576 & 0.343 \\
\hline S4 & -0.552 & 0.181 \\
\hline S5 & -0.531 & 0.249 \\
\hline S6 & 0.642 & -0.322 \\
\hline S7 & 0.735 & -0.134 \\
\hline S8 & 0.540 & -0.383 \\
\hline S9 & 0.485 & -0.172 \\
\hline
\end{tabular}

Tab 7. Factor loadings, principal component factor analysis. Source: survey.

\subsection{Differences in regional identity}

As pointed out above the regional identity index does not measure levels of identity in absolute terms, but allows us to compare the regional identity of various socio-economic groups. A first comparison is that between in- and out-migrants. In-migrants $(0.05)$ do have a slightly more positive identity compared to out-migrants $(-0.08)$, which is not surprising due to the fact that inmigrants did actively decide for the region. It is considerable that out-migrants feel relatively close to the region. The descriptive analysis (see 3.2) has shown some evidence for close contacts to family and friends in the case study region or concrete plans to return to "Waldviertler Wohlviertel". From our analysis we cannot distinguish, however, whether these contacts are the cause or the consequence of the high level of regional identity.

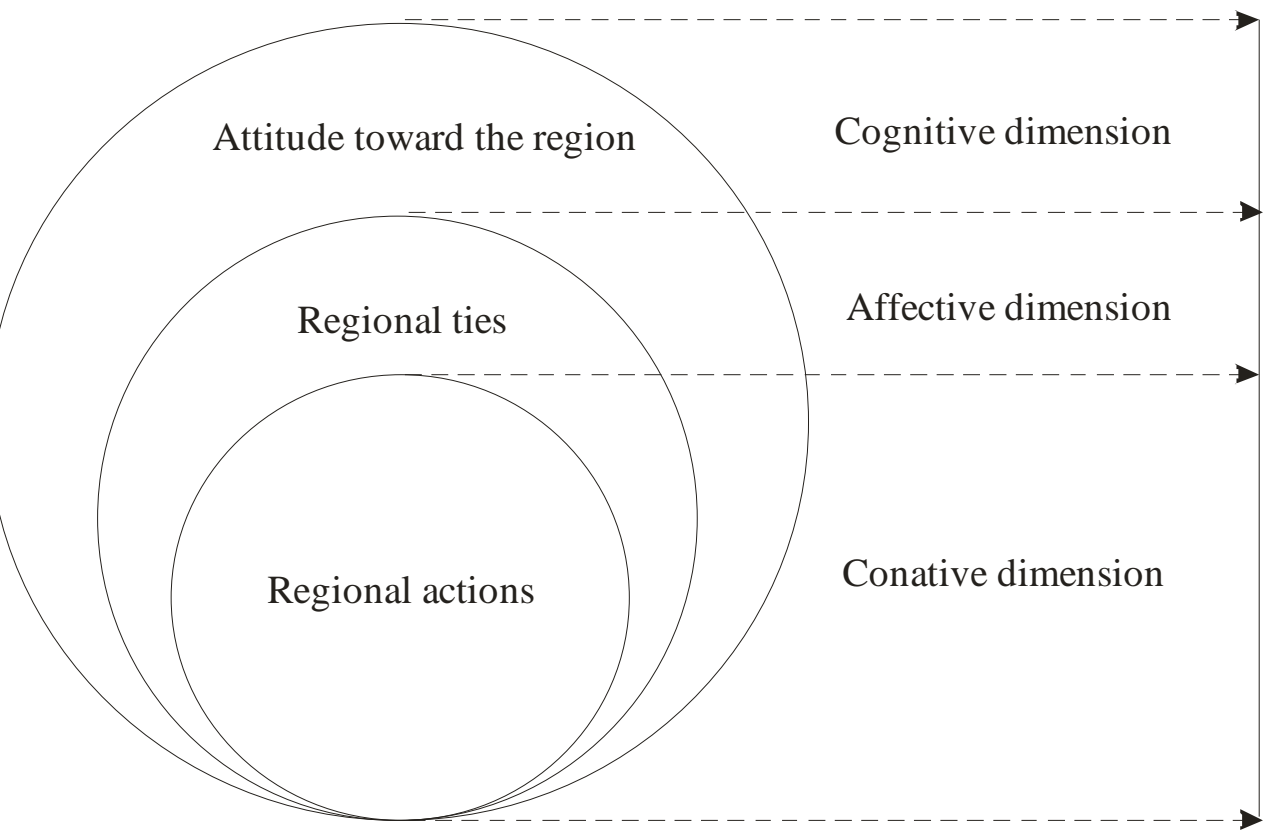

Fig 3. Dimensions of regional identity. Source: Werthmöller 1995, p. 66. 


\begin{tabular}{|c|c|c|c|}
\hline & & In-migration & Out-migration \\
\hline \multirow{7}{*}{ 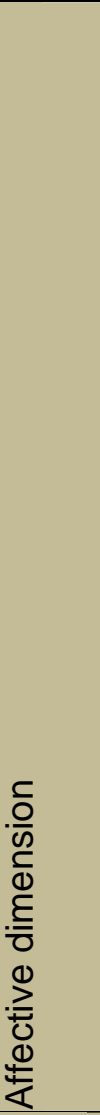 } & (1) sex & $\begin{array}{l}\text { male } \\
\text { female }\end{array}$ & $\begin{array}{l}\text { Male } \\
\text { female }\end{array}$ \\
\hline & (2) age classes & $\begin{array}{l}\text { age class } 1: 15-19 \text { years } \\
\text { age class } 2: 20-29 \text { years } \\
\text { age class } 3: 30-54 \text { years } \\
\text { age class } 4: 55+\text { years }\end{array}$ & $\begin{array}{l}\text { age class } 1: 15-19 \text { years } \\
\text { age class } 2: 20-29 \text { years } \\
\text { age class } 3: 30-54 \text { years } \\
\text { age class } 4: 55+\text { years }\end{array}$ \\
\hline & (3) educational levels & $\begin{array}{l}\text { primary education } \\
\text { (compulsory education, } \\
\text { apprentice training } \\
\text { scheme, vocational } \\
\text { training school) } \\
\text { secondary education } \\
\text { tertiary education } \\
\text { (university, institution of } \\
\text { higher education, college) }\end{array}$ & $\begin{array}{l}\text { primary education } \\
\text { (compulsory education, } \\
\text { apprentice training } \\
\text { scheme, vocational } \\
\text { training school) } \\
\text { secondary education } \\
\text { tertiary education } \\
\text { (university, institution of } \\
\text { higher education, college) }\end{array}$ \\
\hline & (4) employment status & $\begin{array}{l}\text { employed } \\
\text { unemployed } \\
\text { retired } \\
\text { housewife /-man } \\
\text { in education } \\
\end{array}$ & $\begin{array}{l}\text { employed } \\
\text { unemployed } \\
\text { retired } \\
\text { housewife /-man } \\
\text { in education } \\
\end{array}$ \\
\hline & (5) children & $\begin{array}{l}\text { with children } \\
\text { without children }\end{array}$ & $\begin{array}{l}\text { with children } \\
\text { without children }\end{array}$ \\
\hline & (6) commuting & after in-migration & before out-migration \\
\hline & (7) closeness to the region & ------ & $\begin{array}{l}\text { without or low } \\
\text { high }\end{array}$ \\
\hline \multirow{2}{*}{$\sum_{\substack{D \\
\frac{1}{0}}} \frac{\overline{0}}{n}$} & (1) year of migration & $\begin{array}{l}1999 \text { and earlier } \\
2000 \text { and later }\end{array}$ & $\begin{array}{l}1999 \text { and earlier } \\
2000 \text { and later }\end{array}$ \\
\hline & $\begin{array}{l}\text { (2) involvement in } \\
\text { association }\end{array}$ & $\begin{array}{l}\text { yes } \\
\text { no }\end{array}$ & $\begin{array}{l}\text { yes } \\
\text { no }\end{array}$ \\
\hline
\end{tabular}

Tab 8. Socio-economic groups. Source: survey.

The profiles of the nine assessment statements each for in- and out-migrants cover information about the suitability of the region for specific socio-economic groups. This refers to the "cognitive dimension" (see section 2), which is defined as the attitude towards the region. Our hypothesis is that specific socio-economic groups have different attitudes towards the region. There is some evidence that the region is particularly suitable for families with children and for retired people who are mobile, which covers aspects of regional ties (see "affective dimension" as discussed in section 2). The most intensive aspect of regional identity is covered by the "conative dimension" (see section 2), which is manifested in active participation. Our survey contained questions referring to active participation in the region. We will analyse regional identity of various groups of respondents following the three dimensions of regional identity (see Fig 3). The bases of our identity index are the nine assessment statements (see Tab 6) that cover the cognitive dimension. The other two dimensions are captured by distinguishing various socio-economic groups. These groups are summarized for both the affective dimension and the conative dimension in Table 8. 


\subsubsection{The affective dimension of regional identity}

In this section we differentiate the responding out- and in-migrants by the seven variables of the affective dimension that were presented in Tab 8 and compare their mean index values.

(1) Gender

\begin{tabular}{|l|l|l|}
\hline Gender & Means out-migrants* & Means in-migrants* \\
\hline male & $-0,2074$ & 0,0057 \\
\hline female & 0,0142 & 0,0772 \\
\hline All respondents & $-0,0784$ & 0,0483 \\
\hline * not significant between the groups \\
\hline
\end{tabular}

Tab 9. Regional identity of male and female. Source: survey.

Comparing male and female respondents it is evident that in both respondent groups women show a higher degree of regional identity than men (see Tab 9). There are several possible reasons for that. About one fifth (21\%) of the female in-migrants in our sample are housewives and therefore spend most of their daily life in the region, which could be an indicator for developing closer ties to their neighbourhood in the region (closer contact with neighbours and other families with children, etc.). A closer look at the analysis below across the employment status (see Tab 12) supports this proposition. Housewives (there are no housemen in the sample) in the in-migrants' sample show a relatively high degree of regional identity $(0.31)$ due to the fact that most of them are mothers who have a direct contact to other parents, personnel of the kindergarten or schools or other services of the daily life. Women and especially housewives are therefore potential stakeholders for participative activities as long as the success of such involvement largely depends on trust and knowledge and personal ties to other stakeholders (see conative dimension).

(2) Age classes

\begin{tabular}{|l|l|l|}
\hline Age class & Means out-migrants ${ }^{* *}$ & Means in-migrants \\
\hline age class 1 (15-19 years) & 0,0202 & $-0,0718$ \\
\hline age class 2 (20-29 years) & 0,0007 & 0,1545 \\
\hline age class 3 (30-54 years) & $-0,4496$ & $-0,0788$ \\
\hline age class 4 (55+ years) & 0,2663 & 0,0710 \\
\hline All respondents & $-0,0838$ & 0,0462 \\
\hline $\begin{array}{l}\text { * not significant between the groups } \\
\text { ** significant between the groups }\end{array}$
\end{tabular}

Tab 10. Regional identity of age classes. Source: survey.

Following the results of the descriptive analysis respondents belonging to different age classes do have a differentiated relationship with the region. In fact the regional identity varies between the age classes (see Tab 10). For out-migrants the differences between the age groups are statistically significant, whereas for the in-migrants they are not. Looking at the out-migrants, elderly people belonging to the age class 55+ show the strongest identity. This could be interpreted as the result of a long relationship with the region. People belonging to this age group often were born in the region and left the region in later periods of their lives. There is also a strong relationship indicated in the youngest age classes 1 and 2 (15 - 29 years) covering people who left the region after school for tertiary education outside the region. Looking at the different age classes of in-migrants two age classes show a stronger identity than the others. On the one hand the 20-29 years old in-migrants do have the strongest relationship with the region. On the other hand similar to the out-migrants people belonging to the age class 55+ show a higher degree of regional identity. These people are often retired but relatively mobile which implies that they can cope with the relatively large distances someone needs to overcome in the region to satisfy daily needs. 
(3) Educational levels

\begin{tabular}{|l|l|l|}
\hline $\begin{array}{l}\text { Educational } \\
\text { levels }\end{array}$ & Means out-migrants & Means in-migrants* \\
\hline primary & $-0,1189$ & 0,1299 \\
\hline secondary & 0,0570 & $-0,0158$ \\
\hline tertiary & $-0,3051$ & $-0,1358$ \\
\hline All respondents & $-0,0846$ & 0,0419 \\
\hline * not significant between the groups \\
\hline
\end{tabular}

Tab 11. Regional identity of different educational levels. Source: survey.

Looking at the educational levels the hypothesis is that for both in- and out-migrants skilled people are more aware of the strengths and weaknesses in the region. These people are often more mobile and more flexible in terms of their housing locations. Concerning out-migrants, people with low skills (primary educational level) are often forced to change their home location because of missing job opportunities. This might lower their level of regional identity. The analysis of regional identity at different levels of education (see Tab 11) confirms these hypotheses although the results are not statistically significant. The descriptive analysis shows a direct correlation between higher education and out-migration (see Tab 5).

(4) Employment status

\begin{tabular}{|l|l|l|}
\hline Employment status & Means out-migrants* & Means in-migrants* \\
\hline employed & $-0,1606$ & $-0,0340$ \\
\hline unemployed & $-0,5367$ & $-0,0421$ \\
\hline retired & 0,1583 & 0,0528 \\
\hline Housewives/-men & $-0,0402$ & 0,3090 \\
\hline school & $-0,1133$ & 0,3720 \\
\hline All respondents & $-0,1011$ & 0,0427 \\
\hline * not significant between the groups \\
\hline
\end{tabular}

Tab 12. Regional identity of respondents with different employment status. Source: survey.

The outcome of the analysis by employment status (see Tab 12) corresponds to the results of the age classes in Tab 10. The results are not statistically significant, however. Retired outmigrants have a higher regional identity than all other groups. Looking at the in-migrants, three groups show a relatively high regional identity compared to the average of the out-migrants sample. Housewives, pupils and students are the socio-economic groups with the highest regional identity. They are potential target groups for political stakeholders in terms of active participation (see conative dimension) and need to be taken into account for developing target group specific regional strategies. Additionally the level of regional identity of retired people lies slightly above the average of the out-migrants' sample. Referring back to the assessment statements, which are the basis for defining the attitude towards the region (cognitive dimension, see $T a b 6$ ), the region seems to provide a good atmosphere for both stakeholder groups (young and elderly people) and exactly these groups show a relatively high degree of regional identity. This result strengthens the potential for activating specific demographic groups in the region.

(5) Children

\begin{tabular}{|l|l|l|}
\hline Children & Means out-migrants & Means in-migrants* \\
\hline yes & $-0,0451$ & 0,0676 \\
\hline no & $-0,1443$ & $-0,0104$ \\
\hline All respondents & $-0,0784$ & 0,0475 \\
\hline * not significant between the groups \\
\hline
\end{tabular}

Tab 13. Regional identity of respondents with and without children. Source: survey.

\footnotetext{
${ }^{10}$ Details for educational levels see Tab 8
} 
The region has specific characteristics, such as an intact landscape and silence that suggest the hypothesis that the region is suitable for families with children. Looking at the results of the descriptive analysis the in-migrants sample shows that more than $70 \%$ of the people who moved into the region within the period of analysis do have children and approximately $70 \%$ of these people do agree that the region is suitable for families with children. In the out-migrants sample about $64 \%$ do have children and $80 \%$ of the respondents agree that the region is suitable for families with children. In both respondents' groups people with children do have a higher regional identity than those without children. Therefore regional strategies should take into account these demographic groups. The specific results are not statistically significant, however.

(6) Commuting

\begin{tabular}{|l|l|l|}
\hline Commuting & Means out-migrants** & Means in-migrants* \\
\hline yes & $-0,1232$ & 0,1060 \\
\hline no & $-0,2289$ & 0,0197 \\
\hline All respondents & $-0,1824$ & 0,0463 \\
\hline $\begin{array}{l}\text { * not significant between the groups } \\
\text { ** significant between the groups }\end{array}$ \\
\hline
\end{tabular}

Tab 14. Commuting as indicator for regional identity. Source: survey.

The socio-economic criterion commuting distinguishes on the one hand between those outmigrants who were out-commuting from the region before they left it and those who were not, and on the other hand between those in-migrants who after moving to the region commuted out and those who did not. So, the commuters experience the region mainly as a living environment, the non-commuters also as a working environment. Therefore, we interpret the result that those out-migrants, who commuted before they left the region, do have a significantly higher regional identity than those who did not commute (see Tab 14), as an additional indicator for the attractiveness of the region as a place to live. The same result holds for in-migrants, although not statistically significant. These results indicate that the advantages of the region as a place to live may overcompensate the social costs of daily commuting.

(7) Closeness

\begin{tabular}{|l|l|}
\hline Closeness & Means out-migrants ${ }^{\star \star}$ \\
\hline yes & $-0,0123$ \\
\hline no & $-0,2960$ \\
\hline All respondents & $-0,1629$ \\
\hline ** significant between the groups \\
\hline
\end{tabular}

Tab 15. Closeness as indicator for regional identity. Source: survey.

We asked the out-migrants, whether they feel close to the region they left or not. Almost half $(46 \%)$ of the out-migrants do feel close to the region. Many respondents $(\sim 40 \%)$ have close contacts to friends and family living in the case study region, which might be an indicator of feeling close with the region. The results of closeness as an indicator for regional identity fit the results of the descriptive analysis and are statistically significant (see Tab 15).

\subsubsection{The conative dimension of regional identity}

The questionnaire included some participation oriented questions, which could provide information about the degree of participation and involvement. Those questions aiming at particular activities of the LEADER+ region did not provide valid results, because respondents did have sufficient knowledge of these activities. Therefore we only used two socio-economic groups for the conative dimension - (1) the year of migration and (2) active participation in associations. 


\begin{tabular}{|l|l|l|}
\hline Year & Means out-migrants & Means in-migrants* \\
\hline 1999 and earlier & $-0,2184$ & 0,0925 \\
\hline 2000 and later & $-0,0368$ & 0,0107 \\
\hline All respondents & $-0,1297$ & 0,0482 \\
\hline * not significant between the groups \\
\hline
\end{tabular}

Tab 16. Regional identity and year of migration. Source: survey.

The year of migration might have an influence on the level of identification of migrants with the region. We decided to divide the sample at the migration year 2000. This was the year the LEADER+ region was founded and regional participation activities have started. Therefore, the year of migration gives information about both the affective and the conative dimension. The results for out-migrants are relatively clear, although they are statistically not significant. Those respondents who migrated before 2000 have a lower regional identity than those who left the region later. There are two possible reasons for this result. Firstly the longer the respondents are out of the region the more their regional identity deteriorated. Secondly, people who left the region after 2000 did recognise the regional activities started with the foundation of the LEADER+ region in the year 2000. Looking at the in-migrants the reverse pattern arises. It must be taken into account that the results are statistically not significant. The longer in-migrants are in the region, the stronger is their regional identity. For newcomers the attendance time is a crucial indicator for the degree of regional identity. The thesis is that in-migrants need some years to integrate, which is a pre-condition of developing regional identity.

(2) Involvement in associations

\begin{tabular}{|l|l|l|}
\hline association & Means out-migrants** & Means in-migrants* \\
\hline yes & $-0,2805$ & 0,1060 \\
\hline no & 0,0178 & 0,0197 \\
\hline All respondents & $-0,0753$ & 0,0463 \\
\hline $\begin{array}{l}\text { * not significant between the groups } \\
\text { ** significant between the groups }\end{array}$ \\
\hline
\end{tabular}

Tab 17. Involvement in associations as indicator for regional identity. Source: survey.

Involvement in associations is a well known indicator for being integrated in a region. It is also stated that people who are part of an association feel closer to the region because of many personal ties and interests. The results of the out-migrants do not fit that general argument but are statistically significant (see Tab 17). Out-migrants who were member of aregional association do have a significantly lower level of regional identity than those who were not involved in such associations. One possible explanation for this result is self selection in the sense that only those members of associations with a low level of regional identity were willing to leave the region and become out-migrants. For in-migrants we get the expected relationship: Members of regional associations have a higher regional identity, because they are integrated in regional activities and feel close with the region. This result, however, is not statistically significant.

\section{Conclusions}

The aim of the paper was to study regional identity as one important criterion for regional political stakeholders to overcome negative cumulative developments. Especially peripheral rural regions suffer from depopulation, lack of jobs and loss of infrastructure, which strengthens the trend of out-migration.

Regional identity is not well defined but it is used in several concepts of regional economics and economic geography. It is rooted in human geography and here particularly in the German speaking community. Originally the human geographers dealt with regional consciousness which is the amount of spatial attitudes and identifications. Blotevogel et al. (1989) designed three dimensions of regional identity (cognitive, affective and conative) which can be 
understood as three interdependent levels characterizing regional attitudes, regional ties and regional actions (see Fig 3). More recently a growing body of literature in the field of regional identity brings into the discussion new forms of governance (e.g. Keating 1998a; 1998b, MacLeod 2001, MacLeod and Jones 2001, Paasi 2002b, Keating 2004), which consider the above mentioned dimensions of regional identity.

The results of our descriptive analysis based on a postal survey strengthened the proposition that regional identity is one of the key factors for overcoming the negative cumulative process in our case study region. In order to gain more detailed insights into the various aspects of regional identity we generated an index. This index helps to identify differences in regional identity. It was used to compare the regional identity of various groups of respondents along specific socio-economic criteria. In order to embed this analysis into the analytical framework of regional identity, we have designed it along the three dimension of regional identity mentioned above.

The cognitive dimension was embedded in our assessment statements (see Tab 6) which were the baseline for the regional identity index. The affective dimension was included in most of our questions since the questionnaire was designed to find motives for in- and out-migration. The results of the descriptive analysis provided a detailed view on positive aspects for specific socioeconomic groups in the region. We stated that regional identity is likely to vary across age classes or levels of education. The descriptive analysis confirmed most of our hypotheses but does not allow for measuring different levels of regional identity. Among others the region seems to provide a positive atmosphere especially for families with children and elderly people, which was an important anchor for the detailed analysis of regional identity of selected socioeconomic groups. We analysed seven socio-economic groups for the affective dimension and two for the conative dimension.

The results of the socio-economic groups support several of our hypotheses although in many cases the differences between the groups are not statistically significant. Starting with the key statements referring to the suitability of the region for families with children and elderly people, we found that there is indeed a strong level of identification in the disconcerted socio-economic groups. Among the in-migrants, exactly these age classes (55+ and 20-29 years) show higher degrees of regional identity than the other classes. In the out-migrants' sample elderly people and those belonging to the youngest age class (15-19 years) show the highest identity values. This result seems extremely important for the implementation of regional strategies which need to be tailor-made for these specific demographic groups. There is an apparent potential in focusing on such groups in order to reduce the risks of further out-migration. Additionally the higher level of regional identity of the youngest out-migrants who left the region typically for tertiary education seems to be enormously important for the region. These out-migrants are the potential returnees. Stockdale (2006) maintains that "in more economically advanced countries where many rural out-migrants migrate for educational reasons, a return by highly educated and skilled persons could signal an inflow of much needed human capital" (p. 357). The focus on elderly people should take into account that the age class 55+ is getting more and more active and mobile, which could be an advantage in a peripheral region where people have to cope with the relatively large distances to satisfy daily needs.

The correlation between regional identity and educational level supports the socio-economic 2structure of the sample. Many of the in-migrants do belong to the lowest educational level and are therefore relatively satisfied. Those with higher educational skills are more sceptical. In order to provide a better atmosphere for skilled people regional political stakeholders need to define niche strategies taking into account new technological developments and general needs for the aging society subsequently arising from general demographic developments.

To sum up the analysis of the differences of regional identity across several socio-economic groups can be stated as an effective starting point for counter action at the regional level. In order to strengthen the conative dimension in-migrants need to be integrated in such processes which refers again to new forms of governance. These results go in line with the current discussion of rural development policy for the period 2007-2013 in the European Union where participation plays a major role. Especially the Leader Community Initiatives focus on different regional stakeholders within the group of citizens as well as public and private sector stakeholders. Within this context tailor-made involvement along the socio-economic structure 
within the regions plays a major role. As the European Commission emphasizes rural areas are valuable "as a place of beauty, rest and recreation" (http://ec.europa.eu/agriculture/rurdev/index_en.htm) and many residents see a clear advantage in living in an intact natural landscape that offers silence and slowness (Gothenburg strategy of sustainable development) and working in regions apart (Lisbon strategy).

\section{Acknowledgements}

The authors acknowledge the funding provided by the local action group (LAG) "Waldviertler Wohlviertel Thaya-Taffa-Wild" for the project "Menschen+".

\section{References}

[1] Amin, A. (1999). An institutionalist perspective on regional development. International Journal of Urban and Regional Research 23 (2), 365-378.

[2] Amin, A. (2002). Spatialities of Globalisation. Environment and Planning A 34, 385-399.

[3] Amin, A. \& Thrift, N. (1992). Neo-Marshallian nodes in global networks. International Journal of Urban and Regional Research 16, 571-587.

[4] Andersson, A. (1985). Creativity and Regional Development. Papers of the Regional Science Association 56, 5-20.

[5] ARL (2005). Handwörterbuch der Raumordnung. 4. neu bearbeitete Auflage. Hannover: Akademie für Raumforschung und Landesplanung,.

[6] Aydalot, Ph. (1986). Milieux Innovateurs en Europe. Paris: GREMI.

[7] Aydalot, Ph. \& Keeble, D. (1988). High Technology Industry and Innovative Environments: The European Experience. London: Routledge.

[8] Baron, S., Field, J. \& Schuller, T. (Eds.) (2000). Social Capital. Critical Perspectives. Oxford: Oxford University Press.

[9] Bausinger, H. (1980). Heimat und Identität. In Moosmann, E. (Hrsg.), Heimat, Sehnsucht nach Identität, Ästetik und Kommunikation (pp. 13-20), Berlin.

[10] Blotevogel, H.H., Heinritz, G. \& Popp, H. (1989). Regionalbewusstsein. Zum Stand der Diskussion um einen Stein des Anstoßes. Geographische Zeitschrift 77 (2), 65-88.

[11] Brenner, N. (2001). The Limits to Scale? Methodological Reflections on Scalar Structuration. Progress in Human Geography 25, 591-614.

[12] Camagni, R. (1991). Space, Networks and Technical Change: An Evolutionary Approach. Belhaven, London: GREMI.

[13] Crevoisier, O. (1993). Spatial Shifts and the Emergence of Innovative Milieux: The Case of the Jura Region between 1960 and 1990. Environment and Planning C 11, 419-430.

[14] Deas, I. \& Lord, A. (2006). From a New Regionalism to an Unusual Regionalism? The Emergence of Non-standard Regional Spaces and Lessons for the Territorial Reorganisation of the State. Urban Studies 43 (10), 1847-1877.

[15] Derenbach, R. (1988). Regionales Entwicklungsbewußtsein und Handlungsbereitschaft. Modelle, Konzepte und instrumentelle Konsequenzen. Raumforschung und Raumordnung 5-6, 258-264.

[16] DiMaggio, P. (1990). Cultural Aspects of Economic Action and organization. In Friedland, R. \& Robertson, A. (Eds), Beyond the marketplace (pp. 113-36), New York: de Gruyter.

[17] Dobson, A. (2007). Environmental citizenship: towards sustainable development. Sustainable Development 15, 276-285. 
[18] Donaldson, A. (2006). Performing regions: territorial development and cultural politics in a Europe of the regions. Environment and Planning A 38(11), 2075-2092.

[19] Edwards, B. \& Foley, M. (1997). Social Capital and the Political Economy of Our Discontent. American Behavioral Scientist 40(5), 669-678.

[20] European Commission (2006). Synthesis of mid-term evaluations of LEADER+ Programmes. Final report, Brussels.

[21] Fromhold-Eisebith, M. (2004). Innovative Milieu and Social Capital - Complementary or Redundant Concepts of Collaboration-based Regional Development? European Planning Studies 12 (6), 747-765.

[22] Fukuyama, F. (2000). Social Capital and Civil Society. Washington DC: International Monetary Fund. (IMF Working Paper WP/00/74)

[23] Goldstein, H. (1991). Growth centre vs. endogenous development strategies: The case of research parks. In Bergman, E.M., Maier, G. \& Tödtling, F. (Eds.), Regions reconsidered. Economic Networks, Innovation, and local development in industrialized countries (pp. 241-263). London: F.Mansell Publishing Limited.

[24] Hess, M. (2004). 'Spatial' relationships? Towards a reconceptualization of embeddedness. Progress in Human Geography 28 (2), 165-186.

[25] Ipsen, D. (1993). Regionale Identität. Überlegungen zum politischen Charakter einer psychosozialen Raumkategorie. Raumforschung und Raumordnung (1), 9-18.

[26] Keating, M. (1998a). The new regionalism in Western Europe: Territorial restructuring and political change. Cheltenham: Edward Elgar.

[27] Keating, M. (1998b). Is there a regional level of government in Europe? In P. LeGalès \& Ch. Lequesne Eds.). Regions in Europe (pp. 11-29), New York: Routledge.

[28] Keating, M. (2003). The invention of regions: political restructuring and territorial government in Western Europe. In N. Brenner, B. Jessop, M. Jones \& G. MacLeod (Eds.), State/Space. A Reader (pp. 256-277), Oxford: Blackwell Publishers Ltd.

[29] Keating, M. (ed.) (2004). Regions and regionalism in Europe. Cheltenham: Edward Elgar.

[30] Lafferty, W. M. (ed.) (2004). Governance for sustainable development. The challenge of adapting form to function. Cheltenham: Edward Elgar.

[31] Lovering, J. (1999). Theory led by Policy: the Inadequacies of the ,new regionalism'. International Journal of Urban and Regional Research, 23, 379-396.

[32] Lukesch, R. (2007). The LAG-handbook - a guide through the stunning world of local action groups. Retrieved August 28, 2008 from http://ec.europa.eu/agriculture/rur/leaderplus/pdf/library/methodology/lukesch_handbook.p df.

[33] MacLeod, G. (2001). New Regionalism reconsidered: globalization and the remaking of political economic space. International Journal of Urban and Regional Research 25, 804829.

[34] MacLeod, G. \& Jones, M. (2001). Renewing the geography of regions. Environment and Planning D: Society and Space 19, 669-695.

[35] Maillat, D. (1991). The Innovation Process and the Role of the Milieu. In Bergman, E., Maier, G., Tödtling, F. (Eds.). Regions Reconsidered. Economic Networks, Innovation, and Local Development in Industrialized Countries (pp. 103-118), London and New York: Mansell.

[36] Malecki, E.J. (1987). The R\&D Location Decision of the Firm and "Creative" Regions. Technovation 6, 205-222.

[37] Markusen, A. (1999). Fuzzy Concepts, Scanty Evidence, Policy Distance: the Case for Rigour and policy relevance in critical regional studies. Regional Studies 33 (9), 869-884. 
[38] OECD (2002). Improving policy coherence and integration for sustainable development. A checklist. Retrieved September 24, 2008 from OECD Observer:

http://www.oecd.org/dataoecd/61/19/2763153.pdf.

[39] OECD (2007). Institutionalising sustainable development. Paris: OECD.

[40] Paasi, A. (1991). Deconstructing regions: notes on the scales of spatial life. Environment and Planning A 23 (1991), 239-256.

[41] Paasi, A. (2002a). Bounded spaces in the mobile world: deconstructing 'regional identity'. Tijdschrift voor Economische en Sociale Geografie 93 (2), 137-148.

[42] Paasi, A. (2002b). Place and region: regional worlds and words. Progress in Human Geography 26 (6), 802-811.

[43] Paasi, A. (2004). Place and region: Looking through the Prism of Scale. Progress in Human Geography 28 (4), 536-546.

[44] Putnam, R. D. (1993). Making Democracy Work. Civic Traditions in Modern Italy. Princeton: Princeton University Press.

[45] Putnam, R. D. (2001). Bowling Alone: The Collapse and Revival of American Community. New York: Simon \& Schuster Publishing.

[46] Ratti, R., Bramanti, A. \& Gordon, R. (Eds.) (1997). The Dynamics of Innovative Regions: The GREMI Approach. Aldershot: Ashgate.

[47] Ray, Ch. (1999). Endogenous Development in the Era of Reflexive Modernity. Journal of Rural Studies 15 (3), 257-267.

[48] Robertson, R. (1992). Globalization: Social Theory and Global Culture. London: Sage.

[49] Roca, Z. \& Oliveira-Roca, M. (2007). Affirmation of territorial identity: A Development Policy Issue. Land Use Policy 24, 434-442.

[50] Rose, G. (1995). Place and identity: a sense of place. In: D. Massey \& P. Jess (Eds.), In A place in the world? (pp. 87-132). New York: Oxford University Press.

[51] Schuller, T. (2007). Reflections on the Use of Social Capital. Review of Social Economy LXV (1), 11-28.

[52] Stockdale, A. (2002). Towards a typology of out-migration from peripheral areas: a Scottish case study. International Journal of Population Geography 8, 345-364.

[53] Stockdale, A. (2006). Migration: Pre-requisite for rural economic regeneration? Journal of Rural Studies 22, 354-366.

[54] Stockdale, A., Findlay A. \& Short, D. (2000). The repopulation of rural Scotland: opportunity and threat. Journal of Rural Studies 16, 243-257.

[55] Stöhr, W. (1987). Regional innovation complexes. Papers of the Regional Science Association, Vol. 59, 29-44.

[56] Storper, M. (1997). The Regional World: Territorial Development in a Global Economy. New York: Guilford Press.

[57] Tödtling, F. (1990). Räumliche Differenzierung betrieblicher Innovation Erklärungsansätze und empirische Befunde für österreichische Regionen. Berlin: Edition Sigma.

[58] Van Huijstee, M. M., Francken, M. \& Leroy, P. (2007). Partnerships for sustainable development: a review of current literature. Environmental Sciences 4 (2), 75-89.

[59] Van Staveren, I. and Knorringa, P. (2007). Unpacking Social Capital in Economic Development: How Social Relations Matter. Review of Social Economy LXV (1), 107-135.

[60] Voß, J.-P., Bauknecht, D. And Kemp, R. (Eds.) (2006). Reflexive governance for sustainable development. Cheltenham: Edward Elgar. 
[61] Weichart, P. (1989). Regionale Identität - ein sinnvoller Forschungsansatz für die Humangeographie? In E. Aufhauser, R. Giffinger und G. Hatz (Hrsg.), Regionalwissenschaftliche Forschung. Fragestellungen einer empirischen Disziplin, Mitteilungen des Arbeitskreises für Regionalforschung Vol. 19, S. 371-378, Wien.

[62] Weichart, P. (1990). Raumbezogene Identität - Bausteine zu einer Theorie räumlichsozialer Kognition und Identifikation. Schriftenreihe für Forschung und Praxis, Stuttgart.

[63] Werthmöller, E. (1995). Räumliche Identität als Aufgabenfeld des Städte- und Regionenmarketing. Ein Beitrag zur Fundierung des Placemarketing. Frankfurt am Main: Peter Lang Verlag. 